\title{
ANALISIS EFEKTIVITAS MEDIA PEMBELAJARAN E-LEARNING DALAM MENINGKATKAN HASIL BELAJAR SISWA KELAS X PADA PELAJARAN FISIKA
}

\author{
Muhammad Rayhan Affandi, Maryscha Widyawati, Yoga Budi Bhakti. \\ ${ }^{1}$ Prodi Pendidikan Fisika, FMIPA Universitas Indraprasta PGRI Jakarta \\ Email: rayhanaffandi09@gmail.com
}

Diterima: 4 Juli 2020 Disetujui: 1 September 2020

\begin{abstract}
Abstrak
E-learning merupakan sebuah inovasi pembelajaran yang mempunyai kontribusi sangat besar terhadap perubahan kegiatan belajar mengajar. Memadukan media pembelajaran dengan E-learning dalam pembelajaran di kelas membuat siswa tidak jenuh dalam pembelajaran. Tujuan penelitian ini untuk mengetahui efektivitas pengunaan media pembelajaran e-learning dalam meningkatkan hasil belajar fisika siswa. Metode penelitian ini adalaha literature review dengan teknik meta analisis dengan mengkaji artikel tentang pembelajaran e-learning. Hasil penelitian menunjukan bahwa media pembelajaran e-learning sangat efektif dalam meningkatkan hasil belajar fisika siswa. Dengan hasil ini diharapkan guru dapat mengimplementasikan pembelajaran e-leraning dengan menngunakan media pembelajaran dalam kegiatan belajar mengajar.
\end{abstract}

Kata Kunci: : Meta Analisis, E-Learning, Hasil Belajar, Efektivitas.

\begin{abstract}
E-learning is a learning innovation that contributes greatly to the change in teaching and learning activities. Combining learning media with E-learning in classroom learning makes students less saturated in learning. The purpose of this study is to know the effectiveness of the use of e-learning media in improving students' physics learning outcomes. This research method is literature review with meta-analysis technique by reviewing articles on elearning learning. The results showed that e-learning media is very effective in improving students' physics learning outcomes. With these results, teachers are expected to implement e-leraning learning by using learning media in teaching and learning activities.

Keywords: Meta-Analysis, E-Learning, Learning Outcomes, Effectiveness.
\end{abstract}

\section{PENDAHULUAN}

Pendidikan merupakan kebutuhan sepanjang hayat (Sudarsana, 2016). Setiap manusia membutuhkan pendidikan dimanapun ia berada dan sepanjang hidupnya. Pendidikan sangat penting yang artinya tanpa pendidikan manusia akan sulit untuk 
Affandi., Widyawati., Bhakti - Analisis Efektivitas Media ...

berkembang dan menyebabkan manusia akan berada sangat dibelakang (Karsidi, 2005). Salah satu tantangan pendidikan saat ini adalah membangun keterampilan, menurut Suarsana (2013) diantaranya adalah keterampilan melek teknologi informasi dan komunikasi (information \& communication technology literacy skill), keterampilan berpikir kritis (critical thinking skill), keterampilan memecahkan masalah (problem solving skill), keterampilan berkomunikasi efektif (effective communication skill) dan keterampilan berkolaborasi (collaborate skill). Keterampilan tersebut itulah yang menurut Perserikatan Bangsa Bangsa (PBB) merupakan ciri dari masyarakat era global saat ini, yaitu masyarakat berpengetahuan (knowledge-based scoeity) (Chaeruman, 2010).

Cara untuk menghasilkan proses pembelajaran yang berkualitas, tentu terdapat beberapa aspek yang turut mempengaruhi yaitu: pengajaran, penggunaan metode pembelajaran yang menarik dan bervariasi dari perilaku belajar peserta didik, kondisi dan suasana belajar yang kondusif serta penggunaan media pembelajaran yang inovatif dalam menunjang proses belajar mengajar itu sendiri (Astuti \& Bhakti, 2018). Media pembelajaran merupakan salah satu unsur yang memegang peran penting dalam proses pembelajaran selain metode yang digunakan dalam mengajar. (Hartawan, Tastra, \& Pudjawan, 2014).

Menurut Hartawan et al. (2014) dalam mata pelajaran fisika saat proses mengajar di kelas, cenderung para pendidik (guru) kurang kreatif dan inovatif dalam menerapkan media pembelajaran saat mengajar. Selama ini media pembelajaran yang sering digunakan dalam menyampaikan materi yaitu textbook, sedangkan dalam mengunakan powerpoint masih jarang diterapkan. Walaupun telah menggunakan beberapa media dalam menunjang proses pembelajaran akan tetapi hasil belajar siswa masih tergolong rendah. Salah satu faktornya yaitu kurangnya motivasi siwa dalam mempelajari fisika yang dianggap sebagai mata pelajaran yang membosankan (Jamilah et al., 2020) dan menjadi hal yang menakutkan, 
Affandi., Widyawati., Bhakti - Analisis Efektivitas Media ...

sehingga berpengaruh pada hasil Informasi dan Teknologi (IT) juga belajar siswa.

kurang.

Berbagai alternatif untuk Saat ini, perkembangan teknologi memperbaiki kelemahan penerapan informasi dan komunikasi telah pembelajaran fisika harus dilakukan membawa perubahan yang sangat dengan pemanfaatan media besar bagi kemajuan dunia pembelajaran yang inovatif. Dengan pendidikan (Astuti et al., 2018). adanya media pembelajaran yang Seiring dengan perkembangan sesuai dengan kebutuhan dan tersebut media pembelajaran juga karakteristik siswa, diharapkan dapat banyak mengalami perkembangan. membuat pembelajaran akan berlangsung secara efektif dan efesien (Hartawan, Tastra, \& Pudjawan, 2014).

Berdasarkan hasil wawancara dan observasi dengan guru-guru yang telah dilakukan oleh Sri Hartini, dkk (2019) mengatakan bahwa guru-guru jarang menggunakan media pembelajaran, khususnya yang media pembelajaran berbasis Informasi dan Teknologi (IT) seperti media pembelaran berbasis e-learning. Hal ini terjadi sebagai akibat dari sarana dan prasarana khususnya terkait dengan media pembelajaran berbasis Informasi dan Teknologi (IT) yang tersedia kurang, pemahaman serta keterampilan guru untuk merancang media pembelajaran berbasis Bentuk dari perkembangan teknologi informasi yang diterapkan di dunia pendidikan adalah e-learning. $E$ learning merupakan sebuah inovasi yang mempunyai kontribusi sangat besar terhadap perubahan proses pembelajaran, dimana proses belajar tidak lagi hanya mendengarkan uraian materi dari guru tetapi siswa juga melakukan aktivitas lain seperti mengamati, melakukan, mendemonstrasikan dan lain-lain. Materi bahan ajar dapat divisualisasikan dalam berbagai format dan bentuk yang lebih dinamis dan interaktif sehingga siswa akan termotivasi untuk terlibat lebih jauh dalam proses pembelajaran tersebut (Aminoto, Tugiyo \& Pathoni, 2014)

E-learning memiliki karakteristik tidak bergantung pada tempat dan 
Affandi., Widyawati., Bhakti - Analisis Efektivitas Media ...

waktu, menyediakan fasilitas ajar yang telah diajarkan oleh guru. knowledge sharing dan visualisasi Pemanfaatan teknologi dalam pengetahuan lebih aktraktif. pembelajaran menjadi salah satu Pembelajaran berbasis web site yang solusi untuk mengatasi permasalah merupakan bagian dari e-learning merupakan usaha untuk membuat transpormasi proses belajar mengajar kedalam bentuk digital yang dijembatani oleh teknologi internet. Tujuan pembelajaran berbasis web ini menitik beratkan pada efisiensi proses belajar mengajar (herayanti, Fuaddunnazmi, \& Habibi, 2015).

Media pembelajaran e-learning yang mulai digunakan di sekolahsekolah umumnya hanya sebatas pengiriman tugas dan pemberian bahan. Termasuk juga $e$-mail merupakan akun yang digunakan dalam pengiriman tugas kepada guru, sedangkan website sebagai fasilitas dalam mempublikasikan bahan ajar. Siswa hanya sebatas mengirim tugas dan tidak mengetahui tindak lanjut atas tugasnya. Selain itu, bahan yang tersedia di website seringkali hanya di download. Komunikasi antara siswa dan guru hanya sebatas proses belajar mengajar yang berlangsung di dalam kelas. Siswa sering kali mengalami kesulitan dalam memperoleh bahan 
penelitian sejenis sehingga diperoleh paduan data secara kuantitatif (Anwar, 2005). Pengumpulan data dalam penelitian ini dilakukan dengan menelusuri jurnal-jurnal pada situs google scholar (scholar.google.co.id) dengan kata kunci "hasil belajar dengan e-learning". Dari pencarian tersebut didapatkan 8 jurnal yang memenuhi kriteria yaitu minimal memiliki nilai efektifitas dalam hasil penelitian atau terdapat data hasil/uji peningkatan skor hasil pembelajaran antara sebelum (posttest) dan sesudah diterapkannya suatu perlakuan (prestest) yang kemudian dilakukan analisis. Analisis dilakukan dengan metode pembanding untuk menentukan efektifitas penerapan media pembelajaran e-learning. Nilai efektifitas dari hasil uji setiap penelitian diambil untuk menentukan tingkat efektif tindakan pembelajaran terhadap hasil belajar.

\section{HASIL DAN PEMBAHASAN}

Hasil penelitian yang dilakukan dalam analisis meta ini dapat dilihat pada tabel 1. Pada penelitian ini ini, data diolah kembali dengan cara merangkum dan mengambil inti sari hasil penelitian saja.

Nilai efektifitas yang diambil dari nilai hasil uji $\mathrm{N}$-gain yaitu :

$N$ Gain $=\frac{\text { Skor Posttest }- \text { Skor Pretest }}{\text { Skor Ideal }- \text { Skor Pretest }}$

Selanjutnya, data dilaporkan kembali secara deskriptif kuantitatif dan kualitatif. Hasil analisis terkait dengan media pembelajaran $e$ learning dapat dilihat pada Tabel 1.

Berdasarkan hasil analisis yang tersaji, ternyata media pembelajaran E-learning efektif dalam meningkatkan hasil belajar siswa dengan nilai efektifitas terendah $21.72 \%$ sampai tertinggi $94,47 \%$ dengan rata-rata $69,67 \%$.

Hasil analisis lebih lanjut memperlihatkan bahwa setiap penelitian memiliki nilai efektifitas yang berbeda-beda sama seperti pendapat Thursan Hakim bahwa keberhasilan belajar siswa dapat dipengaruhi oleh faktor internal dan faktor eksternal. Faktor internal merupakan faktor yang berasal dari diri sendiri misalnya faktor bakat, kesehatan dan lain-lain. sedangkan faktor eksternal merupakan faktor 
Affandi., Widyawati., Bhakti - Analisis Efektivitas Media ...

yang berasal dari luar diri seperti faktor lingkungan,dan lain-lain.

Tabel 1. Hasil Penelitian Media Pembelajaran E-Learning

\begin{tabular}{|c|c|c|c|c|c|}
\hline No & Judul penelitian & Peneliti & Nama Jurnal & Tahun & $\begin{array}{c}\text { Efektivitas } \\
(\%)\end{array}$ \\
\hline 1 & 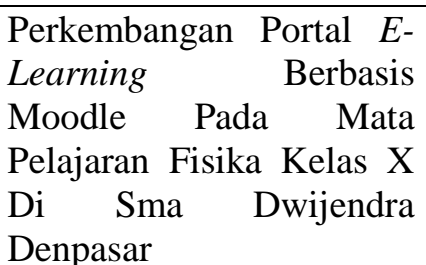 & $\begin{array}{l}\text { Komang } \quad \text { Agus } \\
\text { Hartawan, I Dewa } \\
\text { Kade Tastra, Ketut } \\
\text { Pudjawan }\end{array}$ & $\begin{array}{l}\text { Jurnal } \\
\text { Teknologi } \\
\text { Pendidikan }\end{array}$ & 2014 & 92,39 \\
\hline 2 & $\begin{array}{lr}\text { Perkembangan } & E- \\
\text { Learning } & \text { Berbasis } \\
\text { Schoology Pada Materi } \\
\text { Impuls Dan Momentum } \\
\text { Untuk Melatih Literasi } \\
\text { Digital }\end{array}$ & $\begin{array}{l}\text { Misbah, Wahyu Aji } \\
\text { Pratama, Sri Hartini } \\
\text { dan Dewi } \\
\text { Dewantara }\end{array}$ & $\begin{array}{l}\text { Pancasakti } \\
\text { Science } \\
\text { Education } \\
\text { Journal }\end{array}$ & 2018 & 41 \\
\hline 3 & $\begin{array}{l}\text { Pengembangan Program } \\
\text { Pembelajaran Fisika Sma } \\
\text { Berbasis E-Learning } \\
\text { Dengan Schoology }\end{array}$ & Ismu Wahyudi & $\begin{array}{l}\text { Jurnal Ilmiah } \\
\text { Pendidikan } \\
\text { Fisika Al- } \\
\text { BiRuNi }\end{array}$ & 2017 & 88,83 \\
\hline 4 & $\begin{array}{lr}\text { Pengembangan } & E- \\
\text { Learning } & \text { Menggunakan } \\
\text { Chamilo } & \text { Untuk } \\
\text { Membantu } & \text { Proses } \\
\text { Pembelajaran Fisika } & \text { Sma } \\
\text { Kelas X Semester II }\end{array}$ & $\begin{array}{l}\text { Ayu Rezky Yulita, } \\
\text { Diah Ambarwulan, } \\
\text { Fauzi Bakri }\end{array}$ & $\begin{array}{l}\text { Jurnal Ilmiah } \\
\text { Penelitian dan } \\
\text { Pembelajaran } \\
\text { Fisika }\end{array}$ & 2018 & 94,47 \\
\hline 5 & $\begin{array}{l}\text { Pengaruh Penggunaan E- } \\
\text { Learning } \quad \text { Dengan } \\
\text { Schoology Terhadap } \\
\text { Hasil Belajar Siswa }\end{array}$ & $\begin{array}{ll}\text { Safura } & \text { Rizki } \\
\text { Azizah, } & \text { Agus } \\
\text { Suyatna, } & \text { Ismu } \\
\text { Wahyudi } & \end{array}$ & $\begin{array}{l}\text { Jurnal } \\
\text { Pembelajaran } \\
\text { Fisika }\end{array}$ & 2017 & 61,90 \\
\hline 6 & $\begin{array}{l}\text { Pengembangan } \\
\text { Multimedia Interaktif } \\
\text { Berbasis E-Learning Pada } \\
\text { Pokok Bahasan Besaran } \\
\text { Dan Satuan Di SMA }\end{array}$ & $\begin{array}{l}\text { Tri Wahyuni, Sri } \\
\text { Wahyuni, Yushardi }\end{array}$ & $\begin{array}{l}\text { Jurnal } \\
\text { Pembelajaran } \\
\text { Fisika }\end{array}$ & 2017 & 67,62 \\
\hline 7 & 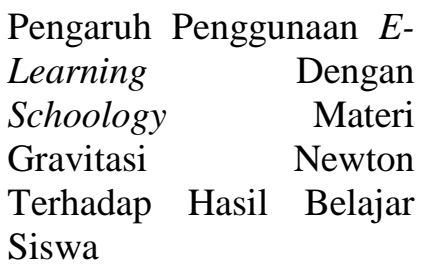 & $\begin{array}{lr}\text { Revania } & \text { Putri } \\
\text { Utami, } & \text { Undang } \\
\text { Rosidin, } & \text { Ismu } \\
\text { Wahyudi } & \end{array}$ & $\begin{array}{l}\text { Jurnal } \\
\text { Pembelajaran } \\
\text { Fisika }\end{array}$ & 2017 & 86,50 \\
\hline 8 & $\begin{array}{lr}\text { E-learning } & \text { dengan } \\
\text { Schoology } & \text { Sebagai } \\
\text { Suplemen Pembelajaran } \\
\text { Fisika Materi Elastisitas } \\
\text { dan Hukum Hooke }\end{array}$ & $\begin{array}{l}\text { Nur Hasanah, Eko } \\
\text { Suyanto, Wayan } \\
\text { Suana }\end{array}$ & $\begin{array}{l}\text { Jurnal } \\
\text { Pembelajaran } \\
\text { Fisika }\end{array}$ & 2016 & 77,27 \\
\hline
\end{tabular}


Affandi., Widyawati., Bhakti - Analisis Efektivitas Media ...

\section{KESIMPULAN DAN SARAN}

Dari penelitian meta-analisis kami bisa disimpulkan bahwa penerapan media pembelajaran $e$ learning yang telah dilakukan oleh para peneliti menunjukan bahwa media pembelajaran $e$-learning efektif dalam meningkatkan hasil belajar siswa dengan nilai efektifitas terendah $21.72 \%$ sampai tertinggi $94,47 \%$ dengan rata-rata $69,67 \%$.

Dari hasil penelitian ini dapat sebagai pertimbangan guru untuk menerapkan e-learning dalam pelajaran fisika agar proses belajar mengajar dapat menjadi lebih efektif dan bisa mendukung siswa dalam belajar yang akan berdampak dengan hasil belajar siswa.

\section{DAFTAR PUSTAKA}

Aminoto, Tugiyo, \& Pathoni, $\mathrm{H}$. (2014). Penerapan Media ELearning Berbasis Schoology Untuk Meningkatkan Aktivitas dan Hasil Belajar Materi Usaha dan Energi Di Kelas XI SMA N 10 Kota Jambi. Jurnal Sainmatika, 1329.

Anwar, R. (2005). Meta analisis. Pertemuan Fertilitas Endokrinologi bagian Obstetri dan Ginekologi RSHS/FKUP, Bandung, 1-20.

Astuti, D. P., Bhakti, Y. B., \& Astuti, I. A. D. (2019, March). Developing Adobe Flashbased mathematics learning media for 7 th-grade students of junior high school. In Journal of Physics: Conference Series (Vol. 1188, No. 1, p. 012098). IOP Publishing.

Astuti, I. A. D., \& Bhakti, Y. B. (2018). Interactive learning multimedia based Microsoft excel on the temperature and heat. Unnes Science Education Journal, 7(1).

Azizah, S. R., Suyatna, A., \& Wahyudi, I. (2017). Pengaruh Penggunaan E-Learning Dengan Schoology Terhadap Hasil Belajar Siswa. Jurnal Pembelajaran Fisika, 5(2).

Chaeruman, U. A. (2010). E-learning dalam pendidikan jarak jauh. jakarta: Kemendiknas.

Hartawan, I. K. A., Tastra, I. D. K., \& Pudjawan, K. (2014). Pengembangan portal elearning berbasis moodle pada mata pelajaran fisika kelas $\mathrm{x}$ di sma dwijendra denpasar. Jurnal Edutech Undiksha, 2(1).

Hartini, S., Susilowati, E., \& Misbah, M. (2019, May). Media 
Affandi., Widyawati., Bhakti - Analisis Efektivitas Media ...

$\begin{aligned} & \text { pembelajaran fisika } \\ & \text { berbasis }\end{aligned}$ e-learning
Kabupaten
sebagai upaya

Herayanti, L., Fuaddunnazmi, M., \& Habibi, H. (2017). Pengembangan perangkat pembelajaran fisika berbasis moodle. Jurnal Pendidikan Fisika dan Teknologi, 3(2), 197-206

Jamilah, P. N., Mulyaningsih, N. N., \& Bhakti, Y. B. (2020). The Effect of Learning Start Learning Strategy With A Question (LSQ) on the Mastery of Physics Concepts. Bulletin of Educational Science and Technology, 1(1), 20-26.

Karsidi, D. (2005). Sosiologi Pendidikan. Solo: UNSPress

Misbah, M., Pratama, W. A., Hartini, S., \& Dewantara, D. (2018). Pengembangan e-learning berbasis schoology pada materi impuls dan momentum untuk melatihkan literasi digital. Relation, 2528(6714), 2541-0628.

Retnawati, H., Apino, E., Kartianom, Djidu, H., \& Anazifa, R. D. (2018). Pengantar Analisis
Meta. Yogyakarta: Parama Publishing.

Suarsana, I. M. (2013). Pengembangan e-modul berorientasi pemecahan masalah untuk meningkatkan keterampilan berpikir kritis mahasiswa. JPI (Jurnal Pendidikan Indonesia), 2(2).

Sudarsana, I. K. (2016). Pemikiran tokoh pendidikan dalam buku lifelong learning: policies, practices, and programs (Perspektif Peningkatan Mutu Pendidikan di Indonesia). Jurnal Penjaminan Mutu, 2(2), 44-53.

Utami, R. P., Rosidin, U., \& Wahyudi, I. (2017). Pengaruh Penggunaan E-Learning Dengan Schoology Materi Gravitasi Newton Terhadap Hasil Belajar Siswa. Jurnal Pembelajaran Fisika, 5(2).

Wahyudi, I. (2017). Pengembangan program pembelajaran fisika sma berbasis e-learning dengan schoology. Jurnal Ilmiah Pendidikan Fisika AlBiRuNi, 6(2), 187-199. 